\title{
MEDIA DAN POLITIK: STUDI KASUS KONSTRUKSI CITRA POLITIK JOKOWI-MA'RUF DAN PRABOWO-SANDIAGA DI KORAN JAWA POS DALAM PEMILU 2019
}

\author{
Nia Silviana ${ }^{1}$, Ucu Martanto $^{2}$ \\ ${ }^{1}$ Departemen Politik, Fakultas Ilmu Sosial dan Ilmu Politik, Universitas Airlangga \\ nia.niasilvi@gmail.com \\ ${ }^{2}$ Departemen Politik, Fakultas Ilmu Sosial dan Ilmu Politik, Universitas Airlangga \\ ucu.martanto@fisip.unair.ac.id
}

\begin{abstract}
This study examines the correlation between reporting by the mass media and the marketing strategies desired by each success team in the 2019 Presidential Election. To find this out, the author uses discourse analysis from Fairclough, because this method is able to show the integration between a) text analysis, $b$ ) analysis of the production process, consumption and distribution of texts, and c) sociocultural analysis. There is no significant difference related to the reporting of Jokowi-Ma'ruf and Prabowo-Sandiaga in the Jawa Pos newspaper, both in qualitative and quantitative terms. Although there are similarities between the political image built by actors and the image constructed by the media, it does not mean that it is based on political cooperation. The selected setting and framing agenda is based on consideration of the selling value of information for the reader. This shows that the mass media as well as the opinion of Croteau and Hoynes (2001) in Stromback (2011) are considered to be oriented towards commercial businesses on how to serve the wants and needs of the audience and advertisers. However, the media and actors are mutually beneficial in this regard, because political reporting is a commodity sought by readers, while political actors need the media to deliver their political products to the public.
\end{abstract}

Keywords: Media, Jawa Pos, Jokowi-Maruf, Prabowo-Sandiaga, 2019 Presidential Election.

\section{PENDAHULUAN}

Sejak era reformasi, pers dijuluki sebagai The Fourth Estate atau pilar ke empat setelah kekuasaan eksekutif, legislatif, dan yudikatif. Julukan ini menempatkan posisi pers sebagai lembaga independen. Hal ini sangat bertolak belakang dengan posisi pers di era sebelumnya, dimana pers hanya menjadi alat pemerintah untuk melanggengkan kekuasaannya. Di era modernisasi, media massa semakin memperluas peranannya dan muncul sebagai salah satu kekuatan baru. Kemampuannya dalam menyebarkan informasi menjadi sumber kekuasaan media massa. Celakanya, dalam konteks kehidupan politik, paradigma memandang media massa tidak seideal seperti apa yang diharapkan sesuai posisi dan perannya. Media massa juga merupakan lembaga partisan yang keberadaan dan keberpihakannya akan berdampak pada kondisi tertentu.

Di Indonesia, eksistensi pemberitaan media massa dalam sistem politik bukan hanya bersumber dari ketertarikannya terhadap nilai atas suatu peristiwa, melainkan juga bisa datang dari rekanan atau permintaan dari kontestan Pemilu itu sendiri, seperti yang dilakukan oleh pasangan KarSa pada Pilgub 2013 pada koran Jawa Pos. Media massa mampu membentuk opini publik, baik opini yang diinginkan oleh politisi atau opini yang diharapkan oleh wartawan. Opini yang terbentuk tidak hanya memengaruhi sikap khalayak terhadap suatu realitas, namun juga tindakan politik. Media massa akan melakukan tiga aktivitas sekaligus dalam pembentukan opini. Pertama, media massa akan menggunakan simbol-simbol politik (language of politics). Aktivitas kedua, yakni melakukan pembingkaian informasi (framing 
strategies). Ketiga, melakukan agenda setting. Dalam melakukan ketiga hal tersebut, media dipengaruhi oleh beberapa faktor, baik internal maupun eksternal. Faktor internal, yakni kebijakan redaksional dalam menyikapi kepentingan politik tertentu, baik kepentingan pengelola media massa, yang bisa saja dipengaruhi oleh hubungan pengelola media dengan kekuatan politik tertentu. Sedangkan faktor eksternalnya, yakni tekanan dari pemirsa, sistem politik yang berlaku serta kekuatan yang selainnya (Hamad, 2004).

Pada Pemilu Presiden 2014, keberpihakan media makin terlihat jelas. Dalam "Partisan Journalism: Review of the Behaviour of Mass Media in Legislative Election and Indonesia Presidential Election of 2014" (2016), Bambang Winarso menemukan eksploitasi terhadap media, baik online, cetak maupun elektronik (radio dan televisi) yang digunakan untuk memenangkan para kandidat presiden. Karenanya pemilihan presiden tahun 2019 menjadi kontestasi yang cukup menarik, sebab kandidatnya adalah aktor yang sama dengan pemilu pada periode sebelumnya, yakni Jokowi dan Prabowo. Dalam Pemilu 2014, Jokowi menang menjadi Presiden Republik Indonesia, sehingga Pemilu kali ini beliau menjadi incumbent.

Secara kuantitas, koalisi pasangan Jokowi-Ma'ruf Amin lebih unggul dibandingkan dengan pasangan Prabowo-Sandiaga. Jokowi-Ma'ruf diusung oleh sembilan partai politik, mulai dari PDIP, Golkar, PKB, PPP, HANURA, NasDem, Perindo, PKPI, dan PSI. Sedangkan pasangan PrabowoSandiaga diusung oleh empat partai, yakni Gerindra, Demokrat, PKS, PAN dan Partai Berkarya. Banyaknya partai pengusung, secara tidak langsung akan berdampak pada luasnya relasi kandidat. Koalisi Paslon 01 dinilai gemuk dengan para penguasa media massa. Nama-nama seperti Erick Thohir, Surya Paloh, dan Hari Tanoesoedibjo adalah beberapa penguasa media massa nasional yang tergabung dalam koalisi Paslon 01. Adhi, sebaliknya di kubu Prabowo, minim dukungan dari pemilik media massa. Kondisi ini dikhawatirkan dapat merugikan masyarakat, karena netralitas pemberitaan akan timpang.

Sebagai salah satu surat kabar yang memiliki oplah banyak di Indonesia, Jawa Pos memiliki kekuatan dalam proses kampanye kandidat dalam Pemilu 2019. Informasi yang disampaikan oleh pihak Jawa Pos tentu akan memengaruhi persepsi pembaca terhadap citra masing-masing calon. Dalam Pilpres 2019, Jawa Pos aktif melakukan pemberitaan kedua pasang calon di salah satu rubriknya, yakni rubrik politika, maupun pada headline.

Dengan demikian, peneliti merumuskan dua pertanyaan penelitian, yakni bagaimana konstruksi citra politik yang dibangun oleh media Jawa Pos terhadap kedua paslon di Pemilu 2019 dan bagaimana relasi antara konstruksi citra yang dibangun oleh media Jawa Pos dengan strategi pemenangan TKN dan BPN dalam Pemilu 2019?

\section{METODE}

Penelitian ini merupakan penelitian kualitatif, dengan menggunakan pendekatan studi kasus. Studi kasus yang diangkat yakni pemberitaan pasangan calon presiden dan wakil presiden di media koran Jawa Pos. Fokus penelitian ini pada konten media dalam melakukan komunikasi dan informasi 
politik kepada khalayak, serta strategi tim sukses dibalik pemberitaan tersebut, bukan kepada pengaruh media terhadap pembaca. Sehingga bisa diketahui bagaimana relasi antara pemberitaan yang diproduksi oleh media dengan strategi pemasaran dari pihak tim suksesnya. Subjek penelitian yang dipilih dalam penelitian ini ada tiga, yaitu media koran Jawa Pos (baik dokumentasi teks koran serta pihak redaksi). Subjek berikutnya, yakni Pak Eddy Tarmidi Widjaja sebagai tim sukses Jokowi-Ma'ruf wilayah Jawa Timur. Subjek yang ketiga, yakni Pak Chairul Fahmi sebagai juru bicara dan pengamat isu di BPN Prabowo-Sandi. Data dalam penelitian ini dikumpulkan dengan studi dokumen dan wawancara. Sedangkan uji keabsahan data menggunakan triangulasi. Analisa data menggunakan analisis teks beserta konteksnya yang diperoleh dari studi dokumen dan wawancara.

\section{KERANGKA TEORI}

\section{Media Massa}

Media dan politik merupakan hal yang tidak dapat dipisahkan. Menurut Kamus Besar Bahasa Indonesia, media massa adalah sarana atau saluran resmi sebagai alat komunikasi untuk menyebarkan berita dan pesan kepada masyarakat luas. Sarana komunikasi ini terdiri dari berbagai macam jenis, diantaranya adalah surat kabar, majalah, buku, radio, dan televisi. Berdasarkan deskripsi tersebut, dapat disimpulkan bahwa media massa merupakan alat penyampaian komunikasi dan informasi yang menyebarkan informasi secara massal dan dapat diakses oleh masyarakat secara luas.

\section{Agenda Setting}

Secara umum, teori agenda setting telah menjelaskan bahwa apa yang menjadi agenda bagi media massa tentu akan linear dengan agenda masyarakat. Dalam hal ini berarti apa yang disampaikan oleh media massa akan menjadi isu yang akan dipikirkan dan dibahas oleh masyarakat. Walter Lipmann dalam Tamburaka (2012) pernah mengutarakan pernyataan bahwa media berperan sebagai mediator antara "The world outside and the pictures in our heads". Hal ini berkesinambungan dengan banyaknya peristiwa yang berpotensi diliput oleh media, namun media memiliki keterbatasan kapasitas untuk meliput dan memberitakan berbagai macam peristiwa yang terjadi. Sehingga, sifat media massa sebenarnya bukan mempermudah khalayak menjangkau peristiwa yang terjadi di luar jangkauannya, namun justru membatasi peristiwa/informasi apa yang harus diketahui oleh khalayak. Hal inilah salah satunya yang menjadi alasan mengapa media massa menjadi kekuatan yang perlu diperhitungkan dalam dunia politik.

Berkembangnya teori agenda setting menstimulus munculnya teori konstrusi realitas politik. Dalam bukunya Ibnu Hamad (2004) menjelaskan bahwa konstruksi realitas politik adalah upaya 'menceritakan' (konseptualisasi sebuah peristiwa, keadaan, atau benda tak terkecuali mengenai hal-hal yang berkaitan dengan politik. Bahasa (baik bahasa verbal maupun bahasa non-verbal) adalah alat konseptualisasi dan alat narasi. Adat tigs cara bagi media massa untuk melakukan konstruksi realitas politik, yakni pemilihan simbol, pemilihan fakta yang akan disajikan, dan kesediaan memberi tempat. 


\section{Priming Dan Framing}

Framing merupakan tahap kedua dari agenda setting. Disebut tahap kedua karena pada tahap framin,g khalayak tidak lagi diajak untuk memikirkan mengenai apa yang seharusnya dipikirkan tetapi justru lebih kepada bagaimana khalayak memikirkan isu tersebut. Analisis framing atau analisis bingkai merupakan versi terbaru dari pendekatan analisis wacana, khususnya untuk menganalisis teks media (Bungin, 2008). Analisis framing dipakai untuk mencermati strategi seleksi, penonjolan, dan pertautan fakta ke dalam berita agar lebih bermakna, lebih menarik, lebih berarti atau lebih diingat, untuk menggiring interpretasi khalayak sesuai perspektifnya.

\section{Analisa Wacana Fairclough}

Analisa wacana dari Fairclough menjembatani bagaimana agenda setting dan framing bekerja pada sebuah berita. Teknik yang digunakan akan mengungkap keterpaduan antara (a) analisis teks, (b) analisis proses produksi, konsumsi, dan distribusi teks, serta (c) analisis konteks yang berkembang di sekitar wacana tersebut (Fairclough, 1995) dalam Hamad (2004).

Tabel 1. Kerangka Kerja Analisis Wacana Fairclough

\begin{tabular}{llllll}
\hline No & Level Masalah & Analisis & Metode Penelitian & \\
\hline 1. & Text & Mikro & Teks eklektif & \\
\hline 2. & Discourse Practise & Meso & $\begin{array}{l}\text { Literatur dibantu dengan interview mendalam } \\
\text { dengan pengelola media }\end{array}$ \\
\hline 3. & Sosiocultural Practice & Makro & $\begin{array}{l}\text { Literatur dibantu dengan interview mendalam } \\
\text { dengan sejumlah pakar sosial dan pakar politik }\end{array}$ \\
\hline
\end{tabular}

Analisa level mikro dilakukan dengan membedah unsur teks eklektif, yakni sebagai berikut:

Tabel 2. Teknik Analisis Wacana Eklektif

\begin{tabular}{|c|c|c|c|c|}
\hline \multirow[t]{2}{*}{ Kerangka Teori } & \multirow[t]{2}{*}{ Pembentuk Teks } & \multicolumn{3}{|c|}{ Evidensi } \\
\hline & & Alat pembuktian & Bukti Teks & Makna \\
\hline \multirow[t]{5}{*}{ Strategi Framing } & \multirow{2}{*}{$\begin{array}{l}\text { Perlakuan } \\
\text { peristiwa }\end{array}$} & Tema yang diangkat & & \\
\hline & & Penempatan berita & & \\
\hline & $\begin{array}{l}\text { Sumber yang } \\
\text { dikutip }\end{array}$ & Nama dan atribut sosial sumber & & \\
\hline & \multirow[t]{2}{*}{ Cara penyajian } & Pilihan fakta yang dimuat & & \\
\hline & & Struktur penyajian & & \\
\hline \multirow[t]{2}{*}{ Fungsi Bahasa } & \multirow{2}{*}{$\begin{array}{l}\text { Simbol yang } \\
\text { dipergunakan }\end{array}$} & Verbal: kata, istilah, frase & & \\
\hline & & Non verbal: foto, gambar & & \\
\hline $\begin{array}{l}\text { Jalan piliran } \\
\text { dikonstruksi. }\end{array}$ & resimpulan) & & & \\
\hline
\end{tabular}

Analisa di level meso, data menggunakan wawancara mendalam dengan para pengelola media yang menjadi "sampel" penelitian. Pencarian data terutama dipusatkan pada text production: proses pembuatan teks (berita kampanye Pemilu) termasuk pertimbangan yang dipakai ketika menyusun teks tersebut; dan text consumption: yaitu tentang bagaimana faktor pembaca diperhitungkan dalam menyusun teks. Pada analisa makro, penggalian data dipusatkan pada tim sukses Jokowi-Ma'ruf dan Prabowo-Sandi sebagai pihak yang bertanggung jawab selama proses kampanye pada Pemilu 2019. (Hamad, 2004) 


\section{PEMBAHASAN}

\section{Deskripsi Pemberitaan Pasangan Jokowi-Ma'ruf dan Prabowo-Sandiaga dalam Harian Jawa Pos (Text Analysis)}

Data yang diambil adalah data sampel selama masa kampanye terbuka pada tanggal 24 Maret-14 April 2019. Penulis menemukan setidaknya terdapat delapan belas berita yang kontennya membahas pasangan Jokowi Maruf secara keseluruhan dan enam berita campuran yang membahas tentang kedua pasang calon. Sedangkan untuk pemberitaaan terkait pasangan Prabowo-Sandi berjumlah tujuh belas berita, selisih satu berita dari pasangan 01 . Sebagian besar berita yang memuat konten masing-masing calon secara penuh ada di rubrik politika, hanya ada dua berita yang ada di headline. Sedangkan berita yang memuat kedua pasang calon dalam satu judul mayoritas ada di headline.

Tabel 3. Pemberitaan Jawa Pos Terhadap Kandidat Capres dan Cawapres pada Pemilu 2019

\begin{tabular}{|c|c|c|c|}
\hline Edisi & Judul Berita 01 & Judul Berita 02 & Berita Campuran \\
\hline 24 Maret 2019 & $\begin{array}{l}- \\
\text { hanya ada iklan Paslon } 01\end{array}$ & - & - \\
\hline 25 Maret 2019 & & & $\begin{array}{l}\text { Jokowi Janjikan Insentif, } \\
\text { Prabowo Turunkan Harga }\end{array}$ \\
\hline 26 Maret 2019 & $\begin{array}{l}\text { Angkat Isu Bandara dan } \\
\text { Tol }\end{array}$ & $\begin{array}{l}\text { Tagline Bergerak dari } \\
\text { Timur }\end{array}$ & $\begin{array}{l}\text { Perkuat Ideologi lewat } \\
\text { Jalur Pendidikan }\end{array}$ \\
\hline 27 maret 2019 & $\begin{array}{l}\text { Mantapkan Dukungan } \\
\text { Ulama }\end{array}$ & $\begin{array}{l}\text { Perbaiki Nasib Warga } \\
\text { Pesisir }\end{array}$ & $\begin{array}{l}\text { Reformasi Birokrasi Tidak } \\
\text { Anti Kritik }\end{array}$ \\
\hline 28 Maret 2019 & $\begin{array}{l}\text { Janjikan Tol Pontianak } \\
\text { Singkawang }\end{array}$ & Bawa Ok Oce ke Papua & $\begin{array}{l}\text { Reformasi Intelijen, Aktif } \\
\text { di Forum Dunia }\end{array}$ \\
\hline 29 Maret 2019 & $\begin{array}{lll}\text { Percepat Proyek Trans } \\
\text { Sulawesi }\end{array}$ & $\begin{array}{l}\text { Tekan Kebocoran dan } \\
\text { Korupsi }\end{array}$ & \\
\hline 30 Maret 2019 & $\begin{array}{l}\text { Terima Dukungan } \\
\text { Millennial Palembang }\end{array}$ & $\begin{array}{l}\text { Siapkan Industri } \\
\text { Pengelolaan Kopra }\end{array}$ & \\
\hline 31 Maret 2019 & & & $\begin{array}{ll}\text { Diawali Saling Curhat } \\
\text { Berakhir Sejuk }\end{array}$ \\
\hline 1 April 2019 & $\begin{array}{l}\text { Tuntaskan Jalur KA dan } \\
\text { Bendungan }\end{array}$ & $\begin{array}{ll}\text { Langsung } & \text { Turunkan } \\
\text { Tarif Listrik } & \\
\end{array}$ & \\
\hline 2 April 2019 & $\begin{array}{l}\text { Rumah untuk Korban } \\
\text { Banjir }\end{array}$ & $\begin{array}{l}\text { OK OCE dan Rumah } \\
\text { Kerja }\end{array}$ & \\
\hline 3 April 2019 & $\begin{array}{l}\text { Gandeng TGB Raup Suara } \\
\text { NTB }\end{array}$ & $\begin{array}{l}\text { Prabowo Serukan Jaga } \\
\text { TPS }\end{array}$ & \\
\hline 4 April 2109 & $\begin{array}{l}\text { Akses Perbankan untuk } \\
\text { Petani }\end{array}$ & $\begin{array}{l}\text { Terima Sumbangan } \\
\text { sebagai Harapan }\end{array}$ & \\
\hline 5 Apri 2019 & Peduli Ekonomi Kreatif & $\begin{array}{l}\text { Benahi Kesejahteraan } \\
\text { Guru Non-PNS }\end{array}$ & \\
\hline 6 April 2019 & Siap Bangun Bulog Rotan & $\begin{array}{l}\text { Listrik Murah dan Harga } \\
\text { Stabil }\end{array}$ & \\
\hline 7 April 2019 & - & - & - \\
\hline 8 April 2019 & $\begin{array}{l}\text { Kampanye Akbar Dibalut } \\
\text { Karnaval Budaya }\end{array}$ & $\begin{array}{l}\text { Prabowo Tegaskan Janji } \\
\text { Perubahan }\end{array}$ & \\
\hline 9 April 2019 & $\begin{array}{l}\text { Kerahkan Majelis Taklim } \\
\text { Untuk Raup Suara }\end{array}$ & $\begin{array}{l}\text { Janjikan Pertumbuhan } \\
\text { Ekonomi } 6,5 \text { Persen }\end{array}$ & \\
\hline 10 April 2019 & $\begin{array}{l}\text { Investasi Besar Yakin } \\
\text { Menang di Karawang }\end{array}$ & $\begin{array}{l}\text { Bikin Senyum Petani } \\
\text { Karet dan Sawit }\end{array}$ & \\
\hline 11 April 2019 & $\begin{array}{lll}\text { Ajak Ulama } & \text { Peduli } \\
\text { Problem Bangsa } & \\
\end{array}$ & $\begin{array}{l}\text { Janji Hindari Politisasi } \\
\text { BUMN }\end{array}$ & \\
\hline 12 April 2019 & $\begin{array}{lrr}\text { Tuntaskan } 3 & \text { Proyek } \\
\text { Infrastruktur } & & \\
\end{array}$ & $\begin{array}{l}\text { Terima Dukungan } \\
\text { Aliansi Advokat }\end{array}$ & \\
\hline 13 April 2019 & $\begin{array}{l}\text { Target Minimal } \\
\text { Suara di Bogor }\end{array}$ & $\begin{array}{l}\text { Bentuk Tim Kuat Untuk } \\
\text { Swasembada }\end{array}$ & \\
\hline 14 April 2019 & $\begin{array}{l}\text { Ajak Bersatu, Optimis } \\
\text { Indonesia Maju }\end{array}$ & & $\begin{array}{l}\text { Adu Gagasan Membangun } \\
\text { Ekonomi }\end{array}$ \\
\hline
\end{tabular}

Sumber: Koran Jawa Pos yang dikelola oleh penulis 
Sesuai dengan unsur teks eklektif yang disampaikan oleh Ibnu Hamad bahwa unsur yang dapat dianalisis dari text analysis adalah fungsi agenda setting, strategi framing, dan fungsi bahasa yang dilakukan oleh media massa dalam memproduksi berita. Berikut text analysis mengenai pemberitaan pasangan Jokowi-Ma'ruf dan Prabowo-Sandiaga dalam Pilpres 2019:

\section{Fungsi Agenda Setting}

Fungsi agenda setting yang telah dijelaskan pada teori adalah bagaimana media massa memperlakukan peristiwa. Merujuk pada pemberitaan Jawa Pos selama periode kampanye terbuka, tema yang banyak disorot terkait Paslon 01 adalah tema mengenai infrastruktur. Sedangkan tema yang banyak disorot terkait Pasangan 02 adalah tema ekonomi. Hal tersebut dapat dilihat dari judul berita yang dimuat, dari 18 berita yang murni memuat Jokowi-Ma'ruf, sebanyak enam berita yang judulnya secara lugas membahas soal infrastrukur, yakni pada edisi 26 Maret, edisi 28 Maret, edisi 29 Maret, edisi 01 April, edisi 06 April, dan edisi 12 April. Selain dari judul berita, tema infrastruktur pasangan Jokowi-Ma'ruf dapat dilihat pada konten pemberitaannya. Contoh kutipan pada edisi 26 Maret 2019, "Dihadapan para pendukungnya, Jokowi berjanji memperpanjang landasan pacu Bandara Banyuwangi agar pesawat berbadan lebar bisa masuk. Dia lantas menyinggung Waduk Bajulmati yang sudah selesai dibangun”.

Selain tema infrastruktur, tema lain yang dominan diangkat yakni relasi Paslon 01 dengan ulama. Setidaknya ada tiga judul berita, yakni di edisi 27 Maret, edisi 06 April, dan edisi 11 April. Selain itu, ada tema dukungan millenial untuk pasangan Jokowi-Ma'ruf sebanyak satu berita, yakni di edisi 30 Maret tema kemanusiaan, edisi 02 April tema kampanye kreatif, edisi berita pada 04 April 2019 dan edisi 05 April, serta tema lain terkait target perolehan suara.

Sedangkan tema pemberitaan Pasangan 02 didominasi dengan tema ekonomi. Sebanyak 11 berita dari 17 berita yang secara penuh memuat berita mengenai Paslon 02. Judul berita yang memuat tema tersebut, yakni edisi 27 Maret, edisi 28 Maret, edisi 29 Maret, edisi 30 Maret, edisi 01 April, edisi 02 April, edisi 05 April, edisi 06 April, edisi 09 April, edisi 10 April, dan edisi 13 April. Tidak hanya judul, dari segi konten juga mendukung tema tersebut. Selain tema ekonomi, tema lain yang dimuat yakni dukungan yang didapatkan Paslon 02 , tema anti politisasi dan korupsi, serta tema terkait Pemilu yang berintegritas. Sedangkan berita-berita yang memuat kedua pasangan calon banyak mengulas tema debat, seperti pendidikan dan pertahanan, politik serta ekonomi.

\section{Strategi Framing}

Bukti-bukti teks yang dapat digunakan dalam menganalisis strategi framing menurut pendapat Hamad (2004), yakni sumber yang dikutip dan cara penyajian, dimana cara penyajian itu sendiri dapat dipahami lagi lebih detail pada pilihan fakta yang dimuat dan struktur penyajian pemberitaannya. Terkait framing pasangan Jokowi-Ma'ruf, beberapa sumber data yang dikutip melibatkan banyak nama yang disertai dengan atribut sosial tertentu, seperti Jokowi selaku "Capres Petahana", "Capres 01", "Mantan Gubernur DKI Jakarta”, "Mantan Walikota Solo”, “Ayah Tiga Anak”, “Alumnus Universitas Gadjah Mada". Selain Jokowi, kutipan dan atribut sosial yang digunakan banyak mengarah pada pihakpihak pendukung Jokowi-Ma'ruf. Sebanyak 10 tokoh lain yang dikutip dalam seluruh pemberitaan Jokowi. 
Framing pasangan Prabowo-Sandi juga menggunakan sumber kutipan dari berbagai pihak yang disertai atribut sosial tertentu. Misalnya, Prabowo sebagai capres yang berpasangan dengan Sandi; "Capres 02", "Mantan Danjen Koppasus", dan "Ketua Umum Partai Gerindra". Pemberitaan mengenai Prabowo-Sandi menggunakan sembilan kutipan dari berbagai tokoh.

Fakta yang banyak diangkat oleh Jawa Pos juga tidak berbeda jauh antara pasangan Jokowi-Ma'ruf dan Prabowo-Sandiaga (terkait tema selain infrastruktur dan ekonomi). Fakta-fakta mengenai pihak-pihak yang mendukung Jokowi-Ma'ruf dan Prabowo-Sandi ditulis dengan sudut pandang pendukung, keluasan pihak yang mendukungnya. Menunjukkan bahwa pasangan Jokowi-Ma'ruf dan Prabowo-Sandi didukung oleh millenial, oleh emak-emak, dan ulama. Hal yang membedakan yakni kesan bahwa Paslon 01 banyak didukung oleh pemimpin di regional.

Fakta-fakta mengenai peristiwa yang terjadi selama masa kampanye, baik berupa kampanye positif maupun hoax yang menimpa Paslon 01 dan 02 ditulis dengan menggunakan sudut pandang pelaku. Misalnya, meskipun Jokowi difitnah sebagai PKI atau Prabowo mengajak masyarakat untuk tidak melakukan money politic. Secara umum, kesan yang dibentuk yakni pasangan Jokowi-Ma’ruf maupun Prabowo-Sandi melakukan Pemilu dengan baik.

\section{Fungsi Bahasa}

Sesuai dengan pendapat Ibnu Hamad (2004) bahwa bahasa (baik bahasa verbal maupun bahasa non-verbal) adalah alat konseptualisasi dan alat narasi. Dalam media massa, bahasa juga bisa menentukan gambaran (makna citra) mengenai suatu realitas-realitas media yang akan muncul di benak khalayak. Bahasa-bahasa verbal yang kerap digunakan oleh Jawa Pos dalam memberitakan pasangan Jokowi-Ma'ruf:

"Joko Widodo memastikan pembangunan infrastruktur akan menjadi prioritas...", “...fokus pembangunan infrastruktur...,,"...menyelesaikan pembangunan...”, “...infrastruktur tuntas, perekonomian meningkat", "menerima dukungan dari milenial", "Konsolidasi dengan ulama...", "Jokowi adalah pemimpin yang dikelilingi oleh para ulama", 'Program andalan...,kartu Indonesia pintar (KIP) kuliah, kartu pra kerja dan kartu sembako murah."

Sedangkan bahasa verbal yang sering digunakan untuk memberitakan pasangan Prabowo-Sandi, yakni:

“... strategi ekonomi yang lebih baik dari pemerintah.”,'Sandi berjanji menjalankan program OK OCE dan rumah pra kerja",,'Pengembangan milenial",",...menurunkan tarif listrik...,",'harga bahan pokok terjangkau",',berdiri di kaki sendiri","dukungan dari ulama", "didukung oleh emak-emak","menerima sumbangan".

Sedangkan untuk bahasa non-verbal, pemberitaan Paslon 01 banyak memuat potret Jokowi dengan para pendukungnya saat kempanye. Ada tiga potret Jokowi dengan Iriana sedang menyapa dan bersalaman dengan kerumunan massa. Selain potret Jokowi, beberapa berita juga memuat potret Ma'ruf Amin sedang berbicara di depan massa. Ada juga yang di mimbar dengan menggunakan sarung, kopyah, dan sorban.

Perihal bahasa non-verbal, komposisi foto yang digunakan dalam pemberitaan Paslon 01 dan 02, memiliki komposisi yang serupa. Perbedaannya adalah detail gambarnya yang digunakan. Dari 17 pemberitaan mengenai Paslon 02, sebanyak empat foto berupa aksi wefie pasangan Prabowo-Sandi dengan para pendukungnya. Kesan yang terbentuk dari potret tersebut, yakni selain makna kekinian, dari swafoto Sandi dengan pendukungnya yang notabene perempuan, mengesankan bahwa pasangan ini juga banyak didukung oleh emak-emak. Selain berswafoto, foto lain yang ditunjukkan yakni pose mengangkat tangan menunjuk angka 02 , serta kampanye di antara massa. 


\section{Interpretasi Makna Pemberitaan Pasangan Jokowi-Ma'ruf dan Prabowo-Sandiaga dalam Harian Jawa Pos (Processing Analysis)}

Pertama, berkaitan dengan fungsi agenda setting yakni bagaimana Jawa Pos memperlakukan fakta mengenai pasangan Jokowi-Ma'ruf pada Pemilu 2019. Berdasarkan pada pilihan tema yang diangkat serta penempatan beritanya bisa dimaknai bahwa Jawa Pos hendak menyampaikan pesan bahwa Jokowi-Ma'ruf adalah pasangan petahana berhasil dalam pembangunan infrastruktur. Setting lain yang ingin disampaikan yakni dukungan dari umat muslim, ulama, generasi millennial, serta pemimpin daerah. Hal tersebut menumbuhkan kesan positif bahwa Paslon 01 lebih layak karena banyak pendukung. Kedua, terkait strategi framing, berdasarkan analisis pengutipan sumber serta atributnya, pilihan fakta yang dimuat, serta struktur penyajian, bisa dimaknai bahwa Jawa Pos hendak membuat frame bahwa Jokowi-Ma'ruf adalah petahana yang berhasil, calon yang didukung ulama serta millenial. Ketiga, mengenai fungsi bahasa verbal dan non-verbal yang digunakan linear dengan kesan yang ingin disampaikan dalam analisa framing. Bahasa non-verbal yang ditunjukkan juga mengesankan bahwa Joko Widodo adalah sosok yang ramah, kepala keluarga yang baik, sedangkan kesan religius banyak diwakili oleh atribut yang digunakan oleh Ma'ruf Amin yang menggunakan baju kokoh, kopyah, sarung dan surban.

Makna pesan yang melekat pada pasangan Prabowo-Sandi berbeda dengan Jokowi-Ma'ruf. Walau demikian, di beberapa hal tidak berbeda jauh dengan pasangan Jokowi-Ma'ruf. Pertama, terkait dengan fungsi agenda setting. Berdasarkan pada pilihan tema yang diangkat serta penempatan beritanya bisa dimaknai bahwa Jawa Pos hendak menyampaikan pesan bahwa Prabowo-Sandi adalah calon presiden dan wakil presiden yang fokus terhadap perbaikan ekonomi, serta calon presiden dan wakil presiden yang juga didukung oleh banyak pihak, khususnya umat muslim serta advokat.

Kedua, terkait strategi framing, kesan yang ditangkap yakni Prabowo-Sandi sebagai calon presiden yang akan menyejahterakan Indonesia dengan membangun ekonomi mandiri dalam negeri, pasangan calon yang memiliki banyak pendukung (kalangan umat islam, emak-emak, dan advokat). Ketiga, mengenai fungsi bahasa yang digunakan memang menciptakan kesan yang linear dengan hasil analisa framing. Bahasa non-verbal yang ditunjukkan juga mengesankan bahwa Prabowo-Sandi adalah sosok yang kekinian dan mampu membaur dengan masyarakat. Pasangan Jokowi-Ma'ruf membangun kesan religius dari perangkat non-verbal, sedangkan PrabowoSandi tidak banyak mengenakan atribut Islam seperti Ma'ruf Amin, melainkan dari kegiatan kampanye dan kutipan bahasa yang digunakan.

\section{Eksplanasi Dasar Pembuatan Liputan dan Pemberitaan Pasangan Jokowi-Ma'ruf dan Prabowo-Sandiaga dalam Harian Jawa Pos (Social Analysis)}

Berita yang diproduksi, dicetak, dan disebarluaskan kepada khalayak tentu ada cerita pembuatan dibalik itu. Istilah yang digunakan oleh Ibnu Hamad (2004) adalah cerita dibalik berita. Perihal variabel konteks, beberapa data seperti struktur berita tetap mengikuti kaidah analisis wacana, yakni fungsi agenda setting, fungsi framing, dan fungsi bahasa. Data tersebut kemudian dipadukan dengan data yang didapatkan dari tiga informan, yakni pihak Jawa Pos serta tim kampanye dari pihak Jokowi-Ma’ruf maupun Prabowo-Sandi. 
Aspek pertama yang akan dibahas yakni dimensi sumber informasi. Secara umum berita didapatkan dari masing-masing peserta Pemilu, yakni kedua pasang calon, pengamat politik atau politikus secara luas. Berikutnya adalah aspek independensi media. Jawa Pos mengakui tidak ada kerjasama dalam proses pembuatan berita dengan kedua pasang calon. Meski ada perbedaan komposisi secara kuantitas, yakni selisih satu berita dengan Paslon 01, bukan berarti Jawa Pos memihak kepada Paslon 01.

Pembuatan berita didasarkan atas komoditas dari konten yang ditulis bagi Jawa Pos sebagai media yang juga menjalankan logika bisnis. Walau menurut Paslon 02, sebagian besar preferensi politik pihak Jawa Pos ke 02. Namun dari hasil analisa teks yang dilakukan, data tersebut tidak linear. Menurut pihak Jawa Pos sendiri, prinsip utama medianya yakni tidak akan mengorbankan medianya sendiri meski ada preferensi politik. Dalam kontestasi skala luas, jika Jawa Pos terlalu berpihak ke salah satu calon saja, bisa jadi akan mengurangi pasar atau pembacanya. Kerja sama yang dilakukan hanya dalam aspek iklan.

Setelah aspek independesi, berikutnya yakni logika yang memengaruhi konten pemberitaan. Sebagaimana menurut Stromback (2005) apabila media ingin mengambil peran utama dalam proses peliputan dan pemberitaan, maka media harus mampu memilah komunikasi politik dan pemerintahan yang dimainkan oleh aktor politik yang bisa dijangkau oleh media dan dipahami oleh khalayak. Sebaliknya, apabila aktor politik ingin mengambil peran utama dalam proses peliputan dan pemberitaan, maka aktor politik tersebut harus dapat mengatur bagaimana komunikasi politik dimainkan, dapat dijangkau, dan dapat dipahami. Dalam hal ini, Jawa Pos yang mengambil alih dalam proses produksi berita sesuai nilai komoditas informasinya.

\section{SIMPULAN}

Citra politik yang ditampakkan oleh Jawa Pos terhadap pasangan Jokowi-Ma'ruf adalah pasangan pertahanan yang berhasil dalam pembangunan infrastruktur; paslon yang didukung oleh banyak kalangan, mulai dari umat muslim (ulama), emak-emak, dan kaum millenial; serta religius baik dari sumber kutipan yang digunakan, maupun dari bahasa non-verbal yang dimuat dalam foto pemberitaan. Sedangkan konstruksi citra politik yang dibangun oleh Jawa Pos terhadap pasangan Prabowo-Sandi adalah calon pemimpin yang peduli dengan kesejahteraan; solutif dalam persoalan ekonomi untuk membangun Indonesia menjadi negara yang mandiri; didukung oleh banyak pihak (ulama, emak-emak, advokat, dan millennial); kekinian, atau adaptif dengan anak muda. Citra yang ditampakkan oleh pihak Jawa Pos linear dengan citra yang dibangun oleh tim sukses masing-masing. Kondisi tersebut tidak ada kaitannya dengan keberpihakan Jawa Pos terhadap salah satu paslon. Terlepas dari adanya perbedaan porsi berita, hal tersebut bukan didasari atas keberpihakan, melainkan konten beritanya memang komoditas bagi para pembaca Jawa Pos. Sehingga orientasi bisnis lebih menonjol dibandingkan kepentingan politiknya, walau preferensinya merujuk pada Paslon 02 . Hal tersebut tidak memengaruhi profesionalitas dalam pembuatan berita. 


\section{DAFTAR PUSTAKA}

Bhaskara A (2018) 'Bukan gagasan Apalagi Nilai': Keberpihakan Media Tiap Pilpres”. Diakses 18 September 2019, dari https://tirto.id/bukan-gagasan-apalagi-nilai-keberpihakan-bos-media-tiappilpres-cZSZ

Bungin B (2008) Sosiologi Komunikasi: Teori, Paradigma, dan Diskursus Teknologi Komunikasi di Masyarakat. Jakarta: Kencana Prenada Media Group.

Hamad I (2004) Konstruksi Realitas Politik dalam Media Massa: Sebuah Studi Critical Discourse Analysis terhadap Berita-Berita Politik. Jakarta: Granit.

Hindarto Y (2019) 'Jokowi Kuasai Media Mainstream, Gerindra andalkan Medsos. Diakses 18 September 2019, dari https://www.cnnindonesia.com/nasional/20180907184136-32328660/jokowi-kuasai-media-mainstream-gerindra-andalkan-medsos

Stromback J (2011) Mediatization of Politics. New York and London: Routledge.

Subiakto H \& Rachmah I (2012) Komunikasi Politik, Media dan Demokrasi. Jakarta: Prenada Media Group.

Tamburaka A (2012) Agenda Setting Media Massa. Jakarta: PT Raja Grafindo Persada. 